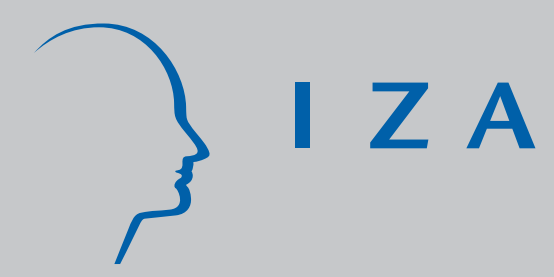

IZA DP No. 1560

Are There Differences in the

Health-Socioeconomic Status Relationship over the Life Cycle? Evidence from Germany

Keith A. Bender

Steffen Habermalz

April 2005 


\title{
Are There Differences in the Health- Socioeconomic Status Relationship over the Life Cycle? Evidence from Germany
}

\author{
Keith A. Bender \\ University of Wisconsin-Milwaukee \\ Steffen Habermalz \\ University of Nebraska at Kearney \\ and IZA Bonn \\ Discussion Paper No. 1560 \\ April 2005
}

IZA

P.O. Box 7240

53072 Bonn

Germany

Phone: +49-228-3894-0

Fax: +49-228-3894-180

Email: iza@iza.org

Any opinions expressed here are those of the author(s) and not those of the institute. Research disseminated by IZA may include views on policy, but the institute itself takes no institutional policy positions.

The Institute for the Study of Labor (IZA) in Bonn is a local and virtual international research center and a place of communication between science, politics and business. IZA is an independent nonprofit company supported by Deutsche Post World Net. The center is associated with the University of Bonn and offers a stimulating research environment through its research networks, research support, and visitors and doctoral programs. IZA engages in (i) original and internationally competitive research in all fields of labor economics, (ii) development of policy concepts, and (iii) dissemination of research results and concepts to the interested public.

IZA Discussion Papers often represent preliminary work and are circulated to encourage discussion. Citation of such a paper should account for its provisional character. A revised version may be available directly from the author. 
IZA Discussion Paper No. 1560

April 2005

\section{ABSTRACT}

\section{Are There Differences in the Health-Socioeconomic Status Relationship over the Life Cycle? Evidence from Germany}

Most research on the relationship between health and socioeconomic status (SES) controls for changing age or investigates the relationship for a particular age range. This paper, however, examines changes in the relationship across ages, as well as controls for potential endogeneity in the health-SES relationship. Using data from German Socio Economic Panel, we find that the health-SES relationship does vary across the life cycle and that endogeneity is an important influence on the relationship. We also find tentative evidence that universal access to health care reduces the impact of income on self-reported health satisfaction.

JEL Classification: I0, I12, J0, J60, C13

Keywords: health, socioeconomic status, endogeneity, life cycle, Germany

Corresponding author:

Steffen Habermalz

University of Nebraska at Kearney

Department of Economics

West Center 306C

Kearney, NE 68847

USA

Email: habermalzs1@unk.edu 
Are There Differences in the Health-Socioeconomic Status Relationship over the Life Cycle? Evidence from Germany

\section{Introduction}

Economists are increasingly researching the links between health and socioeconomic status (SES). In a time when health care costs are increasing and the baby boom generation nears the time when they will be eligible for government provided health care in retirement, understanding the links between health and SES are crucial for society to formulate policies that will overcome these issues.

However, a potentially valuable source of information in the formulation of policy is the examination of the health-SES relationship at different ages. Most research in this literature controls for age or analyzes a particular age group (i.e. older individuals who are nearing retirement), but rarely are direct comparisons made between age groups. This paper examines this issue in detail to elicit possible policy-relevant differences in the health-SES relationship over the life cycle. We employ a nationally representative dataset from the German Socioeconomic Panel (GSOEP) to estimate the health-SES relationship across different age groups. Using German data has the additional advantage of comparing earlier (primarily U.S.) results concerning the effect of income on health to results from a country with universal access to health insurance. Finally, the methodology used in the paper also recognizes the potential for endogeneity between health and SES and corrects for the bias that might result if this endogeneity is ignored. 
The rest of the paper is organized as follows. The next section briefly reviews the literature on the age aspect of the health-SES relationship. Section 3 outlines the empirical methodology and data used. Section 4 reviews the results while a final section concludes the paper.

\section{Brief Literature Review}

Exploring the link between health and SES has a long history outside the economics field, although research by economists has been growing recently. While it is beyond the scope of this paper to give an exhaustive review of either literature, we do discuss here the central findings of the research and identify studies that are related to ours.

Feinstein (1992) and Smith (1999) provide excellent summaries of the (primarily) economics research to date and find that the literature generally has revealed that low SES usually correlates with inferior health outcomes. This general finding, however, hides a diversity of research. For example, health has been measured in a variety of ways - from self assessed physical and mental health to analyzing specific diseases and medical problems. SES itself is also a term that has not been defined consistently throughout the literature - often meaning income, wealth, labor force status, or education, among others. In this paper, we measure SES along the commonly used dimensions of per capita household income and labor force participation, which has been the focus of several recent studies, including Clark and Oswald (1994), Gerlach and Stephan (1996), Theodossiou (1998), Winkelmann and Winkelmann (1998), Bound et al. (1999) and Gertham and Johannesson (2001). ${ }^{1}$

\footnotetext{
${ }^{1}$ Although they do not look at transitions between work and nonwork, Metcalfe et al. (2003) do find worse physical and psychological health among people who change jobs frequently.
} 
One area that has received a good deal of investigation is the health-SES relationship amongst older members of society. For example, Smith and Kington (1997) examine data from nationally representative surveys of the 51 and older population in the US. Their study does not control for endogeneity between health and SES and focuses on income and wealth as the primary measures of SES. They report important differences in health based on income and wealth for this age group, as well as significant differences by race. Grundy and Holt (2000), who also do not control for endogeneity, find similar results for a sample of older British individuals. Salas (2002) examines why the relationship between self-assessed health measures and low income varies across age groups. The conclusion from this study is that the latent health measure is defined much more broadly (that is, covering many illnesses) for older workers and this causes the relatively weak relationship between self-assessed health and low income among older individuals. Yet, little attention is paid to the role of labor market status in these study. While focusing research on older persons is important, it is not sufficient in the current context since there is not reason to think that the health-SES relationship should be stable throughout the life cycle.

As mentioned above, examining the health-SES relationship across different parts of the life cycle has not been a major area of interest. Typically, past research has controlled for age/age groups or possibly some interactions between SES and age (e.g. Winkelmann and Winkelmann 1998) when examining the health-SES relationship in a single regression. The primary exception to this methodology, however, is Gerlach and Stephan (1996) who estimate separate regressions for men and women who are under 30, between 30 and 49 , and over 49 to 
estimate the influence of unemployment on general life satisfaction. They do not, however, examine any aspect of physical health in their study.

A final and important point of discussion involves methodology. Early studies in the literature assumed a unidirectional line of causation that went from SES to health status. However, it is easily seen that the direction of causality may go the other way, with health status impacting SES, leading to a case of endogeneity. With more sophisticated methodology and improved data, more studies have attempted to control for endogeneity with a variety of methodologies. Chapman and Hariharan (1994), for example, use information on previous health in their attempt to control for the endogeneity between current health and income. Smith and Kington (1997), Gerlach and Stephan (1996), and Winkelmann and Winkelmann (1998) use panel datasets to control for individual fixed effects in the health-SES relationship. However, it is unclear if and how much of the endogeneity between SES and health is caused by (fixed) individual effects. There is no doubt that (genetically) predetermined diseases will affect SES variables. On the other hand, it is evident that environmental factors that are not related to fixed individual traits will also have an effect. Thus controlling for fixed effects does alleviate but not eliminate endogeneity.

An alternative to using panel data to control for endogeneity is a more standard multistage econometric methodology which estimates determinants of SES in the first stage and then uses predicted SES in the second stage health regressions. Only two studies employ this more standard correction for wealth-health endogeneity. Adams et al. (2003) uses panel data from the Assets and Health Dynamics of the Oldest Old dataset to estimate the health-SES 
relationship for U.S. residents who have already left the labor force and receive government supplied health care (Medicare). The other study, Hurd and Kapteyn (2003), addresses the interrelationship between health, income, and wealth using data from the U.S. Health and Retirement Study and two Dutch datasets. Both of these studies use multistage estimation procedures to control for endogeneity of health and income and/or wealth, and therefore do correct for endogeneity bias along this dimension.

Both studies have gaps, however. First, they focus exclusively on older individuals, which will mask any differential effects of (endogeneity corrected) income and/or wealth on health over the life cycle. Second, neither examines the endogenous relationship between health and labor force status. Therefore, the following section outlines our approach to address both of these issues and discusses the data used.

\section{Methodology and Data}

To investigate the relationship of health and SES by age, we employ the German SocioEconomic Panel Study (GSOEP), which is a nationally representative longitudinal survey of approximately 22,000 individuals which has a wealth of information on the health status of respondents as well as a variety of SES and demographic variables. The sample used in this paper was obtained from the 2002 wave of the GSOEP and consists of 8737 individuals after selecting respondents who are older than 18 and less than 65 years of age and have valid observations for the variables of interest (discussed below). ${ }^{2}$

\footnotetext{
${ }^{2}$ Note that we employ the version of the GSOEP that includes an over-sampling of people at the top of the earnings distribution.
} 
The basic estimation equation relates a measure of health, $\mathrm{H}$, to measures of SES as well as other covariates, $\mathrm{X}$, and has the following form for respondent $\mathrm{i}$ :

$\mathrm{H}_{\mathrm{i}}=\alpha_{0}+\alpha_{1} \mathrm{SES}_{\mathrm{i}}+\alpha_{2} \mathrm{X}_{\mathrm{i}}+\varepsilon_{\mathrm{i}}$,

where $\alpha_{0}, \alpha_{1}$, and $\alpha_{2}$ are estimated (vectors of) parameters and $\varepsilon_{i}$ is the error term. There are two main sets of variables that attempt to measure SES. First, we include the labor force status of individuals - namely whether respondents are working (the excluded group), unemployed, or out of the labor force. Our expectations about the two groups are twofold. It has been documented that losing ones job leads to a lot of psychological distress. Therefore we expect unemployment to have a negative impact on health satisfaction. However, some individuals choose to exit the labor force (i.e. maternity leave) while others do so involuntarily (discouraged workers). Thus, expectations about the relationship between health satisfaction and being out of the labor force are ambiguous. The second SES-variable included is per capita household income and its square. Most studies that include income as a control find that increases in income tend to increase health, although often a nonlinear relationship is found with very high levels of income correlating with somewhat lower levels of health.

As mentioned in the literature review, however, there is the potential problem of endogeneity. Not only does SES affect health as assumed by eqn (1), but health may affect SES also. We control for this endogeneity by generating predicted (exogenous) values for household per capita income, working, unemployed and out of the labor force. We use a bivariate probit with selection procedure that simultaneously estimates labor force participation and the likelihood of being employed to generate the predicted values for the labor force variables. We estimate household per capita income in a single equation. All predicted values are generated 
using the full sample. ${ }^{3}$ To generate predicted values we employ (instrumental) variables that are correlated with the SES variables but uncorrelated with the health measures. Therefore, in the labor force participation equations, standard variables capturing the number of children living in the household in different age groups (under age 7/under age 18) and German state unemployment rates are assumed to affect labor force participation and working status, respectively. For the income equations, political party activism (from a question about the tendency to support a particular political party), ownership of residence, the size of the living quarters per household member and windfall income from lottery winnings and inheritances (see Meer et al. 2003 for a similar exogenous variable usage) are assumed to correlate with income but not health.

Other important control variables are also available in the GSOEP. Since Germany provides its citizens with universal health insurance, we included a variable if the respondent was covered by government (as opposed to private) health insurance. Only individuals with sufficient income (about \$4500) are eligible to opt out of the government sponsored program. A negative coefficient on this variable would indicate better health outcomes for high income earners in addition to the direct influence discussed earlier. It has been well documented that lifestyle choices influence health. The 2002 wave of the GSOEP for the first time allows constructing the Body Mass Index (BMI) for respondents which we include in our regressions. Additionally we include information about the smoking habits of the individual (every smoked, currently smoke, how many), whether or not he/she is married, gender, interaction between

\footnotetext{
${ }^{3}$ Ideally one would like to run estimate all predicted values for every age-gender category. Due to low cell sizes (i.e. out of the labor force males aged 34-44) this approach is not feasible. While one could employ a different approach for those categories we have chosen to generate the predicted values using the whole sample to maintain consistency and comparability throughout the study.
} 
gender and married, age and age squared. Finally we include educational variables (graduated from high school, apprenticeship, university degree)

For the dependent variable, we examine the individual's self-assessed health satisfaction. Individuals are asked to rate their satisfaction on a ten point scale from not satisfied at all to very satisfied. Due to small cell sizes responses 0-4 are combined. Table 1 reports the frequencies of this health measure for three different age ranges. Unsurprisingly, health generally becomes worse as age increases. For example, there is a greater percentage of those who are not satisfied with their health (10.3 percent) in the oldest age group, compared to the youngest age group (7.6 percent). ${ }^{4}$

\section{Results}

\section{A. Overall Estimates}

Table 2 contains the results of the health satisfaction regressions where odd numbered columns do not include a correction for endogeneity while even numbered columns do. Concentrating on column (1) we see that the results are similar to those found in the literature. Being unemployed correlates with lower health satisfaction although there is no statistically significant relationship between health satisfaction and being out of the labor force. The relationship between income and health satisfaction appears concave but, due to the very small coefficient on income squared, is increasing over the relevant range of income. Smoking leads to lower health satisfaction, while marriage is positively correlated with health satisfaction. There is a U-shaped relationship between age and health satisfaction, with higher levels of health

\footnotetext{
${ }^{4}$ Economists are generally suspicious of subjective evaluations of health issues. However, research by Hurd and McGarry (1997) shows that self-assessed health is highly predictive of mortality. Therefore, it is likely to be an important avenue for exploration of the relationship between aspects of SES and health.
} 
satisfaction at the beginning and end of the age range. ${ }^{5}$ Finally and not surprisingly, the BMI is negatively related to health satisfaction and is highly significant. Interestingly, there is little difference in the statistical significance of these variables across genders as seen in columns (3) and (5). A notable exception is the fact that health satisfaction among women is not correlated with having ever smoked. The coefficient on the government insurance variable is negative and significant indicating better health outcomes for those that are covered by private health insurance.

However as mentioned above, the estimation results on the primary SES variables, labor force status and income, could be the result of endogeneity. Therefore, the even numbered columns show the results correcting for endogeneity, and the correction clearly has an effect. The relationship between unemployment and health satisfaction, while still negative, is statistically significant for the full sample and for men but is now statistically insignificant for women. On the other hand, the inverse $\mathrm{U}$ shaped relationship between health satisfaction and household income remains for the overall sample, but this is driven by the female sample, as household income is no longer a statistically significant determinant of health satisfaction for men. Interestingly the government health insurance variable, while remaining fairly significant in the full sample, fails to be statistically significant for either women or men. The BMI and other covariates remain statistically significant throughout.

\section{B. Results by Age}

\footnotetext{
${ }^{5}$ According to the coefficients on the age and age squared variables, the age at which health satisfaction is minimized is around 62 years of age, ceteris paribus.
} 
The results in Tables 1 and 2 indicate that age may play an important role in determining these health outcomes. However, the results in Tables 2 are not allowed to differ by age. This may be important if, for example, unemployment has differential effects depending on where a person is in his or her life cycle, as unemployment may mean different things to someone at the beginning of their work life when he or she is trying to accumulate human capital, compared to someone who is close to the end of working life and retirement. To allow for this, we split the sample into three age ranges: $19-34,35-44$, and 45-65 year olds and re-estimate the regressions to see if there are differences in the health-SES relationship across these different age groups.

Table 3, 4 and 5 contain the results from the health satisfaction regressions by age group for the full sample, males and females respectively. For young workers (male or female), only government insurance is statistically significant (and negative) in the non-endogeneity corrected regressions. Indeed the results seem to indicate that older individuals drive the results for the full sample as unemployment is particularly important for the 35-44 age group, while household income is statistically significant for workers older than 44 . However, the endogeneity correction offers a different view of the results. After the correction, unemployment generates lower health satisfaction than working for the youngest age group, primarily driven by young males. On the other hand, the negative effect of unemployment is no longer statistically significant for the older groups once endogeneity is controlled for. Interestingly, while income still has no effect on health satisfaction for the youngest group, it assumes growing importance with age, a result that is mainly driven by the positive impact on per capita household income on health satisfaction of women in the higher age categories. There is no differential effect of the type of health insurance coverage in any of the endogeneity-corrected regressions, an indication 
that the system of universal government provided health insurance does not necessarily lead to lower health outcomes.

\section{Conclusions}

This study examines the relationship between health and SES as defined by labor force status and per capita household income in a system with universal access to health care. The analysis examines the relationship at different points in the life cycle to identify any differences across age groups. Finally, we also control for endogeneity that may be present in the healthSES relationship. The results imply that important differences in the SES-health relationship exist across age groups. Income has an increasingly important effect on the health satisfaction of women over the life cycle while the effect of unemployment on health satisfaction if strongest from young males. This result indicates that it is important to differentiate policies by age and take into account the two-way relationship between health and SES when analyzing data. Finally, the absence of a consistent impact of income on health satisfaction compared to other studies and the fact that there was no statistical evidence for better health outcomes for individuals with private health insurance indicate that access to health insurance might play a larger role than commonly believed in the literature. 


\section{References}

Adams P., Hurd M. D., McFadden D., Merrill A. and Ribeiro T. (2003) 'Healthy, Wealthy and Wise? Tests for Direct Causal Paths Between Health and Socioeconomic Status’, Journal of Econometrics 112: 3-56.

Bound J., Schoenbaum M., Stinebrickner T. R. and Waidmann T. (1999) 'The Dynamic Effects of Health on the Labor Force Transitions of Older Workers', Labour Economics 6: 179202.

Chapman K.S. and Hariharan G. (1994) 'Controlling for Causality in the Link from Income to Mortality’, Journal of Risk and Uncertainty 8: 85-93.

Clark A. E. and Oswald A. J. (1994) 'Unhappiness and Unemployment', Economic Journal 104: 648-59.

Feinstein J. (1992) 'The Relationship between Socioeconomic Status and Health: A Review of the Literature’, Milbank Quarterly 71(2): 279-322.

Gerdtham U.-G. and Johannesson M. (2001) 'The Relationship between Happiness, Health, and Socio-Economic Factors: Results Based on Swedish Microdata', The Journal of SocioEconomics 30: 553-7.

Gerlach K. and Stephan G. (1996) 'A Paper on Unhappiness and Unemployment in Germany', Economic Letters 52(3): 325-330.

Grundy E. and Holt G. (2000) 'Adult Life Experiences and Health in Early Old Age in Great Britain’, Social Science \& Medicine 51: 1061-74.

Hurd M. and Kapteyn A. (2003) 'Health, Wealth, and the Role of Institutions', Journal of Human Resources 38(2): 387-415.

Hurd M. and McGarry K. (1997) 'Evaluation of the Subjective Probabilities of Survival in the Health and Retirement Study’, Journal of Human Resources 30: S268-292.

Meer J., Miller D. L. and Rosen H. S. (2003) 'Exploring the Health-Wealth Nexus', Journal of Health Economics 22: 713-30.

Metcalfe C., Smith G. D., Sterne J.A.C., Heslop P., Macleod J. and Hart C. (2003) 'Frequent Job Change and Associated Health’, Social Science \& Medicine 56: 1-15.

Salas C. (2002) 'On the Empirical Association between Poor Health and Low Socioeconomic Status at Old Age’, Health Economics 11(3): 207-20.

Smith J.P. (1999) 'Healthy Bodies and Thick Wallets: The Dual Relation between Health and Economic Status’, Journal of Economic Perspectives 13(2): 145-66. 
Smith J.P. and Kington R.S. (1997) 'Race, Socioeconomic Status and Health in Late Life' in Martin L.G. and Soldo B.J. (eds.) Racial and Ethnic Differences in the Health of Older Americans, Washington, D.C.: National Academy Press: 106-62.

Theodossiou I. (1998) 'The Effects of Low-Pay and Unemployment on Psychological WellBeing: A Logistic Regression Approach’, Journal of Health Economics 17: 85-104.

Winkelmann L. and Winkelmann R. (1998) 'Why are the Unemployed so Unhappy? Evidence from Panel Data’, Economica 65(257): 1-15. 
Table 1. Percentage Frequencies of Health Status Measures by Age

\begin{tabular}{lrrrr} 
& All Ages & $19-34$ & $35-44$ & $45-65$ \\
\hline Satisfaction with Health & & & & \\
Not satisfied at all & 9.3 & 7.6 & 9.0 & 10.3 \\
{$[1]$} & 10.6 & 6.9 & 10.4 & 12.6 \\
{$[2]$} & 8.7 & 7.1 & 8.3 & 9.9 \\
{$[3]$} & 17.6 & 15.2 & 17.8 & 18.7 \\
{$[4]$} & 28.5 & 29.3 & 29.8 & 27.1 \\
{$[5]$} & 15.8 & 20.0 & 16.0 & 13.6 \\
Very satisfied & 9.5 & 13.9 & 8.8 & 7.8 \\
\hline
\end{tabular}

Source: 2002 GSOEP. Percentages may not add to 100 due to rounding. 
Table 2. Results from Satisfaction with Health Regressions

\begin{tabular}{|c|c|c|c|c|c|c|c|}
\hline \multirow{3}{*}{$\begin{array}{l}\text { Endogeneity } \\
\text { Correction? }\end{array}$} & \multicolumn{3}{|c|}{ Full Sample } & \multicolumn{2}{|c|}{ Males } & \multicolumn{2}{|c|}{ Females } \\
\hline & No & & Yes & No & Yes & No & Yes \\
\hline & $(1)$ & & $(2)$ & (3) & $(4)$ & (5) & $(6)$ \\
\hline Unemployed & $\begin{array}{l}-0.024 * \\
-(2.393)\end{array}$ & & $\begin{array}{l}-0.018 * * \\
-(2.019)\end{array}$ & $\begin{array}{l}-0.266 * \\
-(1.824)\end{array}$ & $\begin{array}{l}-0.024 * * \\
-(2.074)\end{array}$ & $\begin{array}{l}-0.231 * \\
-(1.653)\end{array}$ & $\begin{array}{r}-0.008 \\
-(.633)\end{array}$ \\
\hline Out of Labor Force & $\begin{array}{r}-0.037 \\
-(.588)\end{array}$ & & $\begin{array}{r}-3.9 E-04 \\
-(.187)\end{array}$ & $\begin{array}{l}-0.382 \\
-(1.586)\end{array}$ & $\begin{array}{r}-0.004 \\
-(.301)\end{array}$ & $\begin{array}{r}-0.026 \\
-(.386)\end{array}$ & $\begin{array}{r}0.001 \\
(.219)\end{array}$ \\
\hline HH-Income & $\begin{array}{l}0.003 * \\
(4.952)\end{array}$ & $* * *$ & $\begin{array}{l}0.004 * * \\
(2.197)\end{array}$ & $\begin{array}{l}0.003 \text { *** } \\
(4.048)\end{array}$ & $\begin{array}{r}0.001 \\
(.618)\end{array}$ & $\begin{array}{l}0.002 * \\
(1.864)\end{array}$ & $\begin{array}{l}0.010 * * * \\
\quad(2.9)\end{array}$ \\
\hline HH-Income $^{2}$ & $\begin{array}{c}-1.0 \mathrm{E}-06 * \\
-(3.219)\end{array}$ & $* * *$ & $\begin{array}{c}-5.3 \mathrm{E}-06 * \\
-(1.85)\end{array}$ & $\begin{array}{l}-1.2 \mathrm{E}-06 * * * \\
-(3.243)\end{array}$ & $\begin{array}{r}-2.1 \mathrm{E}-06 \\
-(.694)\end{array}$ & $\begin{array}{r}3.3 \mathrm{E}-07 \\
(.233)\end{array}$ & $\begin{array}{c}-2.2 \mathrm{E}-05 * \\
-(1.885)\end{array}$ \\
\hline Currently Smoking & $\begin{array}{r}0.017 \\
(.23)\end{array}$ & & $\begin{array}{r}0.020 \\
(.271)\end{array}$ & $\begin{array}{l}0.154 \\
(1.502)\end{array}$ & $\begin{array}{r}0.149 \\
(1.45)\end{array}$ & $\begin{array}{r}-0.073 \\
-(.639)\end{array}$ & $\begin{array}{r}-0.058 \\
-(.511)\end{array}$ \\
\hline Ever Smoked & $\begin{array}{l}-0.062 \\
-(1.261)\end{array}$ & & $\begin{array}{l}-0.064 \\
-(1.311)\end{array}$ & $\begin{array}{l}-0.148 * * \\
-(2.088)\end{array}$ & $\begin{array}{l}-0.143 * * \\
-(2.019)\end{array}$ & $\begin{array}{r}0.031 \\
(.46)\end{array}$ & $\begin{array}{r}0.018 \\
(.266)\end{array}$ \\
\hline How many Smoke & $\begin{array}{l}-0.012 * \\
-(3.788)\end{array}$ & *** & $\begin{array}{l}-0.010 * * * \\
-(3.047)\end{array}$ & $\begin{array}{l}-0.011 * * * \\
-(2.72)\end{array}$ & $\begin{array}{l}-0.008 * \\
-(1.843)\end{array}$ & $\begin{array}{l}-0.017 * * * \\
-(3.11)\end{array}$ & $\begin{array}{l}-0.016 * * * \\
-(2.895)\end{array}$ \\
\hline Gov. Health Insurance & $\begin{array}{l}-0.166 * \\
-(3.303)\end{array}$ & $* * *$ & $\begin{array}{l}-0.113 * \\
-(1.877)\end{array}$ & $\begin{array}{l}-0.184 * * * \\
-(2.79)\end{array}$ & $\begin{array}{l}-0.126 \\
-(1.539)\end{array}$ & $\begin{array}{l}-0.138 * \\
-(1.754)\end{array}$ & $\begin{array}{r}-0.063 \\
-(.698)\end{array}$ \\
\hline Body Mass Index & $\begin{array}{l}-0.056 * \\
-(11.568)\end{array}$ & $* * *$ & $\begin{array}{l}-0.057 * * * \\
-(11.58)\end{array}$ & $\begin{array}{l}-0.062 * * * \\
-(8.028)\end{array}$ & $\begin{array}{l}-0.060 * * * \\
-(7.79)\end{array}$ & $\begin{array}{l}-0.052 * * * \\
-(8.272)\end{array}$ & $\begin{array}{l}-0.053 * * * \\
-(8.344)\end{array}$ \\
\hline Married & $\begin{array}{c}0.139 \\
(2.177)\end{array}$ & $* *$ & $\begin{array}{r}0.076 \\
(.895)\end{array}$ & $\begin{array}{c}0.128 * \\
(1.82)\end{array}$ & $\begin{array}{r}0.011 \\
(.123)\end{array}$ & $\begin{array}{l}0.125 * \\
(1.865)\end{array}$ & $\begin{array}{r}0.080 \\
(.818)\end{array}$ \\
\hline Male & $\begin{array}{l}0.133 \\
(1.847)\end{array}$ & $*$ & $\begin{array}{l}0.130 * \\
(1.727)\end{array}$ & & & & \\
\hline Male*Married & $\begin{array}{r}-0.025 \\
-(.294)\end{array}$ & & $\begin{array}{r}-0.013 \\
-(.126)\end{array}$ & & & & \\
\hline Age & $\begin{array}{l}-0.085 * \\
-(6.018)\end{array}$ & $* * *$ & $\begin{array}{l}-0.101 * * * \\
-(5.506)\end{array}$ & $\begin{array}{l}-0.086 * * * \\
-(4.153)\end{array}$ & $\begin{array}{l}-0.113 * * * \\
-(4.272)\end{array}$ & $\begin{array}{l}-0.085 * * * \\
-(4.398)\end{array}$ & $\begin{array}{l}-0.084 * * * \\
-(3.121)\end{array}$ \\
\hline $\operatorname{Age}^{2}$ & $\begin{array}{l}0.001 * \\
(4.329)\end{array}$ & $* * *$ & $\begin{array}{l}0.001 * * * \\
(4.171)\end{array}$ & $\begin{array}{l}0.001 * * * \\
(3.124)\end{array}$ & $\begin{array}{l}0.001 * * * \\
(3.519)\end{array}$ & $\begin{array}{l}0.001 * * * \\
(3.101)\end{array}$ & $\begin{array}{l}0.001 \text { ** } \\
(2.032)\end{array}$ \\
\hline High School & $\begin{array}{l}0.094 \\
(1.487)\end{array}$ & & $\begin{array}{l}0.074 \\
(1.117)\end{array}$ & $\begin{array}{r}0.043 \\
(.458)\end{array}$ & $\begin{array}{r}0.034 \\
(.347)\end{array}$ & $\begin{array}{l}0.131 \\
(1.516)\end{array}$ & $\begin{array}{r}0.067 \\
(.736)\end{array}$ \\
\hline Apprenticeship & $\begin{array}{r}0.002 \\
(.035)\end{array}$ & & $\begin{array}{r}-0.045 \\
-(.772)\end{array}$ & $\begin{array}{l}-0.089 \\
-(1.192)\end{array}$ & $\begin{array}{c}-0.148 * \\
-(1.79)\end{array}$ & $\begin{array}{l}0.079 \\
(1.106)\end{array}$ & $\begin{array}{r}0.044 \\
(.524)\end{array}$ \\
\hline University Degree & $\begin{array}{r}0.073 \\
(.937)\end{array}$ & & $\begin{array}{r}0.042 \\
(.519)\end{array}$ & $\begin{array}{r}0.103 \\
(.952)\end{array}$ & $\begin{array}{r}0.085 \\
(.759)\end{array}$ & $\begin{array}{r}0.047 \\
(.413)\end{array}$ & $\begin{array}{r}-0.003 \\
-(.022)\end{array}$ \\
\hline
\end{tabular}

Notes: Numbers under estimated coefficients are z-scores. ${ }^{*}, * *, * * *$ indicate $10 \%, 5 \%$ and $1 \%$ significance, respectively. Cut-points were also estimated and available upon request. 
Table 3. Results from Health Satisfaction Regressions by Age: Full Sample

\begin{tabular}{|c|c|c|c|c|c|c|}
\hline \multirow{4}{*}{$\begin{array}{l}\text { Endogeneity } \\
\text { Correction? }\end{array}$} & \multicolumn{4}{|c|}{ Full Sample } & \multirow{2}{*}{\multicolumn{2}{|c|}{$45-65$}} \\
\hline & \multicolumn{2}{|c|}{$18-34$} & \multicolumn{2}{|c|}{$35-44$} & & \\
\hline & No & Yes & No & Yes & No & Yes \\
\hline & (1) & (2) & (3) & (4) & (5) & (5) \\
\hline Unemployed & $\begin{array}{r}-0.071 \\
-(.399)\end{array}$ & $\begin{array}{l}-0.041 * * \\
-(2.458)\end{array}$ & $\begin{array}{l}-0.492 * * \\
-(2.407)\end{array}$ & $\begin{array}{r}0.012 \\
(.562)\end{array}$ & $\begin{array}{l}-0.257 * \\
-(1.664)\end{array}$ & $\begin{array}{r}-0.006 \\
-(.409)\end{array}$ \\
\hline Out of Labor Force & $\begin{array}{r}0.000 \\
(.001)\end{array}$ & $\begin{array}{r}-0.003 \\
-(.757)\end{array}$ & $\begin{array}{r}0.030 \\
(.269)\end{array}$ & $\begin{array}{r}0.001 \\
(.222)\end{array}$ & $\begin{array}{r}-0.122 \\
-(1.27)\end{array}$ & $\begin{array}{r}0.001 \\
(.229)\end{array}$ \\
\hline HH-Income & $\begin{array}{r}0.000 \\
(.129)\end{array}$ & $\begin{array}{r}0.005 \\
(.51)\end{array}$ & $\begin{array}{l}0.002 * \\
(1.859)\end{array}$ & $\begin{array}{l}0.006 \\
1.079\end{array}$ & $\begin{array}{l}0.003 * * * \\
(4.581)\end{array}$ & $\begin{array}{l}0.005 * * \\
(2.51)\end{array}$ \\
\hline HH-Income $^{2}$ & $\begin{array}{r}-1.1 \mathrm{E}-06 \\
-(.384)\end{array}$ & $\begin{array}{r}-6.1 \mathrm{E}-05 \\
-(.983)\end{array}$ & $\begin{array}{r}8.1 \mathrm{E}-07 \\
(.341)\end{array}$ & $\begin{array}{r}-3.1 \mathrm{E}-05 \\
(1.304)\end{array}$ & $\begin{array}{l}-1.3 \mathrm{E}-06 \text { *** } \\
-(3.437)\end{array}$ & $\begin{array}{l}-6.6 \mathrm{E}-06 * * \\
-(2.092)\end{array}$ \\
\hline Currently Smoking & $\begin{array}{l}-0.275 * * \\
-(2.14)\end{array}$ & $\begin{array}{r}-0.083 \\
-(.531)\end{array}$ & $\begin{array}{l}-0.165 * \\
-(1.857)\end{array}$ & $\begin{array}{l}-0.204 \\
(1.870)\end{array}$ & $\begin{array}{l}-0.126 * \\
-(1.783)\end{array}$ & $\begin{array}{l}-0.105 \\
-(1.181)\end{array}$ \\
\hline Ever Smoked & $\begin{array}{l}-0.116 \\
-(.674)\end{array}$ & $\begin{array}{r}-0.094 \\
-(.543)\end{array}$ & $\begin{array}{l}0.173 \\
(1.335)\end{array}$ & $\begin{array}{l}0.163 \\
1.259\end{array}$ & $\begin{array}{r}-0.034 \\
-(.307)\end{array}$ & $\begin{array}{r}-0.033 \\
-(.299)\end{array}$ \\
\hline How many Smoke & $\begin{array}{l}0.130 \\
(1.074)\end{array}$ & $\begin{array}{l}0.123 \\
(1.019)\end{array}$ & $\begin{array}{l}-0.211 * * \\
-(2.445)\end{array}$ & $\begin{array}{l}-0.203 * * \\
(2.357)\end{array}$ & $\begin{array}{r}-0.046 \\
-(.663)\end{array}$ & $\begin{array}{r}-0.042 \\
-(.595)\end{array}$ \\
\hline Gov. Health Insurance & $\begin{array}{l}-0.016 * * \\
-(2.188)\end{array}$ & $\begin{array}{l}-0.010 \\
-(1.234)\end{array}$ & $\begin{array}{l}-0.016 * * * \\
-(2.961)\end{array}$ & $\begin{array}{l}-0.017 * * * \\
(2.972)\end{array}$ & $\begin{array}{c}-0.008 * \\
-(1.7)\end{array}$ & $\begin{array}{l}-0.008 \\
-(1.563)\end{array}$ \\
\hline Body Mass Index & $\begin{array}{l}-0.053 * * * \\
-(5.472)\end{array}$ & $\begin{array}{l}-0.051 \text { *** } \\
-(5.214)\end{array}$ & $\begin{array}{l}-0.058 * * * \\
-(6.708)\end{array}$ & $\begin{array}{l}-0.058 \text { *** } \\
(6.706)\end{array}$ & $\begin{array}{l}-0.059 * * * \\
-(7.867)\end{array}$ & $\begin{array}{l}-0.059 * * * \\
-(7.891)\end{array}$ \\
\hline Married & $\begin{array}{r}0.089 \\
(.709)\end{array}$ & $\begin{array}{r}0.024 \\
(.137)\end{array}$ & $\begin{array}{r}0.085 \\
(.739)\end{array}$ & $\begin{array}{l}0.127 \\
0.843\end{array}$ & $\begin{array}{r}0.164 \\
(1.54)\end{array}$ & $\begin{array}{r}0.121 \\
(.824)\end{array}$ \\
\hline Male & $\begin{array}{l}0.165 \\
(1.538)\end{array}$ & $\begin{array}{l}0.176 \\
(1.403)\end{array}$ & $\begin{array}{r}0.0943 \\
(.683)\end{array}$ & $\begin{array}{c}0.0903 \\
0.607\end{array}$ & $\begin{array}{r}0.111 \\
(.795)\end{array}$ & $\begin{array}{r}0.115 \\
(.799)\end{array}$ \\
\hline Male*Married & $\begin{array}{r}-0.111 \\
-(.638)\end{array}$ & $\begin{array}{r}-0.201 \\
-(.902)\end{array}$ & $\begin{array}{r}0.010 \\
(.062)\end{array}$ & $\begin{array}{c}0.016 \\
0.087\end{array}$ & $\begin{array}{r}0.009 \\
(.057)\end{array}$ & $\begin{array}{r}0.065 \\
(.354)\end{array}$ \\
\hline Age & $\begin{array}{l}0.224 \\
(1.633)\end{array}$ & $\begin{array}{r}0.061 \\
(.4)\end{array}$ & $\begin{array}{r}-0.197 \\
-(.544)\end{array}$ & $\begin{array}{r}-0.200 \\
(0.552)\end{array}$ & $\begin{array}{r}-0.060 \\
-(.569)\end{array}$ & $\begin{array}{r}-0.019 \\
-(.173)\end{array}$ \\
\hline $\mathrm{Age}^{2}$ & $\begin{array}{l}-0.005 * \\
-(1.859)\end{array}$ & $\begin{array}{r}-0.002 \\
-(.771)\end{array}$ & $\begin{array}{r}0.002 \\
(.457)\end{array}$ & $\begin{array}{l}0.002 \\
0.465\end{array}$ & $\begin{array}{r}4.9 \mathrm{E}-04 \\
(.503)\end{array}$ & $\begin{array}{r}8.8 \mathrm{E}-05 \\
(.083)\end{array}$ \\
\hline High School & $\begin{array}{r}0.073 \\
(.63)\end{array}$ & $\begin{array}{r}-0.041 \\
-(.314)\end{array}$ & $\begin{array}{r}-0.033 \\
-(.319)\end{array}$ & $\begin{array}{r}-0.025 \\
(0.225)\end{array}$ & $\begin{array}{l}0.233 \text { ** } \\
(2.033)\end{array}$ & $\begin{array}{l}0.237 * * \\
(2.021)\end{array}$ \\
\hline Apprenticeship & $\begin{array}{r}-0.014 \\
-(.137)\end{array}$ & $\begin{array}{l}-0.186 \\
-(1.478)\end{array}$ & $\begin{array}{r}0.046 \\
(.501)\end{array}$ & $\begin{array}{c}0.081 \\
0.759\end{array}$ & $\begin{array}{r}-0.019 \\
-(.238)\end{array}$ & $\begin{array}{r}-0.021 \\
-(.233)\end{array}$ \\
\hline University Degree & $\begin{array}{r}-0.069 \\
-(.45)\end{array}$ & $\begin{array}{r}-0.137 \\
-(.858)\end{array}$ & $\begin{array}{l}0.153 \\
(1.172)\end{array}$ & $\begin{array}{c}0.183 \\
1.320\end{array}$ & $\begin{array}{r}0.009 \\
(.07)\end{array}$ & $\begin{array}{r}-0.002 \\
-(.013)\end{array}$ \\
\hline
\end{tabular}

Notes: Numbers under estimated coefficients are z-scores. ${ }^{*}, * *, * * *$ indicate $10 \%, 5 \%$ and $1 \%$ significance, respectively. Other regressors include those listed in Table 2. 
Table 4. Results from Health Satisfaction Regressions by Age: Males

\begin{tabular}{|c|c|c|c|c|c|c|}
\hline \multirow{4}{*}{$\begin{array}{l}\text { Endogeneity } \\
\text { Correction? }\end{array}$} & \multicolumn{4}{|c|}{ Males } & \multirow{2}{*}{\multicolumn{2}{|c|}{$45-65$}} \\
\hline & \multicolumn{2}{|c|}{$18-34$} & \multicolumn{2}{|c|}{$35-44$} & & \\
\hline & No & Yes & No & Yes & No & Yes \\
\hline & (1) & (2) & (3) & (4) & (5) & (5) \\
\hline Unemployed & $\begin{array}{r}-0.205 \\
-(.809)\end{array}$ & $\begin{array}{l}-0.042 * \\
-(1.787)\end{array}$ & $\begin{array}{l}-0.604 * \\
-(1.937)\end{array}$ & $\begin{array}{l}0.032 \\
(1.154)\end{array}$ & $\begin{array}{r}-0.105 \\
-(.479)\end{array}$ & $\begin{array}{r}-0.015 \\
-(.807)\end{array}$ \\
\hline Out of Labor Force & $\begin{array}{r}-0.270 \\
-(.62)\end{array}$ & $\begin{array}{r}0.011 \\
(.637)\end{array}$ & $\begin{array}{l}-0.992 * \\
-(1.861)\end{array}$ & $\begin{array}{r}0.001 \\
(.064)\end{array}$ & $\begin{array}{r}-0.071 \\
-(.203)\end{array}$ & $\begin{array}{r}-0.023 \\
-(.767)\end{array}$ \\
\hline HH-Income & $\begin{array}{r}4.4 \mathrm{E}-04 \\
(.173)\end{array}$ & $\begin{array}{r}0.008 \\
(.628)\end{array}$ & $\begin{array}{l}0.004 \\
(1.518)\end{array}$ & $\begin{array}{r}0.005 \\
(.707)\end{array}$ & $\begin{array}{l}0.004 * * * \\
(4.397)\end{array}$ & $\begin{array}{r}0.002 \\
(.957)\end{array}$ \\
\hline HH-Income2 & $\begin{array}{r}-1.3 E-06 \\
-(.379)\end{array}$ & $\begin{array}{r}-8.4 \mathrm{E}-05 \\
-(1.159)\end{array}$ & $\begin{array}{r}-1.1 \mathrm{E}-05 \\
-(1.135)\end{array}$ & $\begin{array}{r}-2.3 E-05 \\
-(.883)\end{array}$ & $\begin{array}{l}-1.6 \mathrm{E}-06 * * * \\
-(3.706)\end{array}$ & $\begin{array}{r}-3.2 \mathrm{E}-06 \\
-(.943)\end{array}$ \\
\hline Currently Smoking & $\begin{array}{l}-0.449 * * * \\
-(2.578)\end{array}$ & $\begin{array}{l}-0.232 \\
-(1.044)\end{array}$ & $\begin{array}{r}-0.072 \\
-(.631)\end{array}$ & $\begin{array}{l}-0.180 \\
-(1.221)\end{array}$ & $\begin{array}{l}-0.202 * * \\
-(2.173)\end{array}$ & $\begin{array}{l}-0.176 \\
-(1.439)\end{array}$ \\
\hline Ever Smoked & $\begin{array}{l}-0.356 \\
-(1.397)\end{array}$ & $\begin{array}{r}-0.343 \\
-(1.34)\end{array}$ & $\begin{array}{l}0.554 * * * \\
(3.039)\end{array}$ & $\begin{array}{l}0.503 \text { *** } \\
(2.759)\end{array}$ & $\begin{array}{r}0.065 \\
(.449)\end{array}$ & $\begin{array}{r}0.052 \\
(.355)\end{array}$ \\
\hline How many Smoke & $\begin{array}{l}0.402 * * \\
(2.125)\end{array}$ & $\begin{array}{l}0.379 * * \\
(2.013)\end{array}$ & $\begin{array}{l}-0.457 * * * \\
-(3.647)\end{array}$ & $\begin{array}{l}-0.445 * * * \\
-(3.547)\end{array}$ & $\begin{array}{l}-0.113 \\
-(1.137)\end{array}$ & $\begin{array}{l}-0.101 \\
-(1.014)\end{array}$ \\
\hline Gov. Health Insurance & $\begin{array}{l}-0.012 \\
-(1.256)\end{array}$ & $\begin{array}{r}-0.005 \\
-(.481)\end{array}$ & $\begin{array}{l}-0.018 * * * \\
-(2.584)\end{array}$ & $\begin{array}{l}-0.021 * * * \\
-(2.658)\end{array}$ & $\begin{array}{l}-0.008 \\
-(1.354)\end{array}$ & $\begin{array}{r}-0.005 \\
-(.858)\end{array}$ \\
\hline Body Mass Index & $\begin{array}{l}-0.080 * * * \\
-(5.07)\end{array}$ & $\begin{array}{l}-0.076 * * * \\
-(4.822)\end{array}$ & $\begin{array}{l}-0.052 * * * \\
-(3.709)\end{array}$ & $\begin{array}{l}-0.052 * * * \\
-(3.667)\end{array}$ & $\begin{array}{l}-0.063 * * * \\
-(5.384)\end{array}$ & $\begin{array}{l}-0.059 * * * \\
-(5.089)\end{array}$ \\
\hline Married & $\begin{array}{r}-0.033 \\
-(.226)\end{array}$ & $\begin{array}{l}-0.196 \\
-(1.027)\end{array}$ & $\begin{array}{r}0.107 \\
(.906)\end{array}$ & $\begin{array}{l}0.218 \\
(1.298)\end{array}$ & $\begin{array}{l}0.226 * * \\
(1.975)\end{array}$ & $\begin{array}{r}0.093 \\
(.631)\end{array}$ \\
\hline Age & $\begin{array}{l}0.577 \text { *** } \\
(2.777)\end{array}$ & $\begin{array}{l}0.479 * * \\
(2.029)\end{array}$ & $\begin{array}{r}-0.306 \\
-(.586)\end{array}$ & $\begin{array}{r}-0.343 \\
-(.658)\end{array}$ & $\begin{array}{r}-0.085 \\
-(.565)\end{array}$ & $\begin{array}{r}-0.130 \\
-(.771)\end{array}$ \\
\hline Age2 & $\begin{array}{l}-0.011 * * * \\
-(2.902)\end{array}$ & $\begin{array}{l}-0.009 * * \\
-(2.282)\end{array}$ & $\begin{array}{r}0.004 \\
(.536)\end{array}$ & $\begin{array}{r}0.004 \\
(.609)\end{array}$ & $\begin{array}{r}0.001 \\
(.501)\end{array}$ & $\begin{array}{r}0.001 \\
(.765)\end{array}$ \\
\hline High School & $\begin{array}{r}-0.149 \\
-(.825)\end{array}$ & $\begin{array}{l}-0.301 \\
-(1.505)\end{array}$ & $\begin{array}{r}-0.096 \\
-(.608)\end{array}$ & $\begin{array}{r}-0.050 \\
-(.299)\end{array}$ & $\begin{array}{l}0.272 * \\
(1.759)\end{array}$ & $\begin{array}{l}0.313 * * \\
(1.969)\end{array}$ \\
\hline Apprenticeship & $\begin{array}{r}-0.099 \\
-(.624)\end{array}$ & $\begin{array}{l}-0.224 \\
-(1.207)\end{array}$ & $\begin{array}{r}-0.117 \\
-(.915)\end{array}$ & $\begin{array}{r}-0.024 \\
-(.165)\end{array}$ & $\begin{array}{r}-0.065 \\
-(.568)\end{array}$ & $\begin{array}{r}-0.110 \\
-(.883)\end{array}$ \\
\hline University Degree & $\begin{array}{r}0.006 \\
(.029)\end{array}$ & $\begin{array}{r}0.026 \\
(.115)\end{array}$ & $\begin{array}{l}0.260 \\
(1.402)\end{array}$ & $\begin{array}{l}0.313 \\
(1.619)\end{array}$ & $\begin{array}{r}-0.064 \\
-(.371)\end{array}$ & $\begin{array}{r}-0.124 \\
-(.679)\end{array}$ \\
\hline
\end{tabular}

Notes: Numbers under estimated coefficients are z-scores. *, **, *** indicate $10 \%, 5 \%$ and $1 \%$ significance, respectively. Other regressors include those listed in Table 2. 
Table 5. Results from Health Satisfaction Regressions by Age: Females

\begin{tabular}{|c|c|c|c|c|c|c|}
\hline \multirow{4}{*}{$\begin{array}{l}\text { Endogeneity } \\
\text { Correction? }\end{array}$} & \multicolumn{4}{|c|}{ Females } & \multirow{2}{*}{\multicolumn{2}{|c|}{$45-65$}} \\
\hline & \multicolumn{2}{|c|}{$18-34$} & \multicolumn{2}{|c|}{$35-44$} & & \\
\hline & No & Yes & No & Yes & No & Yes \\
\hline & (1) & (2) & (3) & (4) & (5) & (5) \\
\hline Unemployed & $\begin{array}{r}0.086 \\
(.336)\end{array}$ & $\begin{array}{l}-0.033 \\
-(1.396)\end{array}$ & $\begin{array}{l}-0.406 \\
-(1.507)\end{array}$ & $\begin{array}{r}-0.022 \\
-(.643)\end{array}$ & $\begin{array}{l}-0.382 * \\
-(1.752)\end{array}$ & $\begin{array}{r}0.016 \\
(.786)\end{array}$ \\
\hline Out of Labor Force & $\begin{array}{r}0.065 \\
(.437)\end{array}$ & $\begin{array}{r}-0.003 \\
-(.674)\end{array}$ & $\begin{array}{r}0.063 \\
(.547)\end{array}$ & $\begin{array}{r}2.0 \mathrm{E}-04 \\
(.052)\end{array}$ & $\begin{array}{l}-0.142 \\
-(1.373)\end{array}$ & $\begin{array}{l}0.011 \\
(1.422)\end{array}$ \\
\hline HH-Income & $\begin{array}{r}0.001 \\
(.397)\end{array}$ & $\begin{array}{r}0.002 \\
(.099)\end{array}$ & $\begin{array}{r}0.003 \\
(1.41)\end{array}$ & $\begin{array}{l}0.030 \text { ** } \\
(2.219)\end{array}$ & $\begin{array}{l}0.003 * \\
(1.742)\end{array}$ & $\begin{array}{l}0.013 \text { *** } \\
(3.071)\end{array}$ \\
\hline HH-Income2 & $\begin{array}{r}-8.1 \mathrm{E}-06 \\
-(.729)\end{array}$ & $\begin{array}{r}-9.1 \mathrm{E}-06 \\
-(.033)\end{array}$ & $\begin{array}{r}2.1 \mathrm{E}-06 \\
(.317)\end{array}$ & $\begin{array}{c}-2.4 \mathrm{E}-04 * * \\
\quad-(2.361)\end{array}$ & $\begin{array}{r}-1.7 \mathrm{E}-06 \\
-(.681)\end{array}$ & $\begin{array}{c}-2.6 \mathrm{E}-05 * * \\
-(2.042)\end{array}$ \\
\hline Currently Smoking & $\begin{array}{r}-0.050 \\
-(.258)\end{array}$ & $\begin{array}{r}0.098 \\
(.436)\end{array}$ & $\begin{array}{l}-0.312 * * \\
-(2.172)\end{array}$ & $\begin{array}{l}-0.223 \\
-(1.353)\end{array}$ & $\begin{array}{r}-0.024 \\
-(.216)\end{array}$ & $\begin{array}{r}0.028 \\
(.204)\end{array}$ \\
\hline Ever Smoked & $\begin{array}{r}0.135 \\
(.56)\end{array}$ & $\begin{array}{r}0.133 \\
(.557)\end{array}$ & $\begin{array}{r}-0.101 \\
-(.537)\end{array}$ & $\begin{array}{r}-0.090 \\
-(.473)\end{array}$ & $\begin{array}{r}-0.137 \\
-(.759)\end{array}$ & $\begin{array}{r}-0.096 \\
-(.526)\end{array}$ \\
\hline How many Smoke & $\begin{array}{r}-0.047 \\
-(.297)\end{array}$ & $\begin{array}{r}-0.042 \\
-(.266)\end{array}$ & $\begin{array}{r}0.030 \\
(.248)\end{array}$ & $\begin{array}{r}0.019 \\
(.157)\end{array}$ & $\begin{array}{r}0.047 \\
(.47)\end{array}$ & $\begin{array}{r}0.034 \\
(.336)\end{array}$ \\
\hline Gov. Health Insurance & $\begin{array}{l}-0.028 * * \\
-(2.425)\end{array}$ & $\begin{array}{l}-0.022 * \\
-(1.823)\end{array}$ & $\begin{array}{l}-0.019 * * \\
-(2.185)\end{array}$ & $\begin{array}{l}-0.017 * \\
-(1.873)\end{array}$ & $\begin{array}{l}-0.011 \\
-(1.201)\end{array}$ & $\begin{array}{l}-0.014 \\
-(1.542)\end{array}$ \\
\hline Body Mass Index & $\begin{array}{l}-0.037 * * * \\
-(2.966)\end{array}$ & $\begin{array}{l}-0.035 * * * \\
-(2.768)\end{array}$ & $\begin{array}{l}-0.059 * * * \\
-(5.32)\end{array}$ & $\begin{array}{l}-0.058 * * * \\
-(5.222)\end{array}$ & $\begin{array}{l}-0.058 * * * \\
-(5.768)\end{array}$ & $\begin{array}{l}-0.061 * * * \\
-(6.037)\end{array}$ \\
\hline Married & $\begin{array}{r}0.090 \\
(.679)\end{array}$ & $\begin{array}{r}0.065 \\
(.33)\end{array}$ & $\begin{array}{r}0.051 \\
(.436)\end{array}$ & $\begin{array}{r}-0.015 \\
-(.088)\end{array}$ & $\begin{array}{l}0.158 \\
(1.468)\end{array}$ & $\begin{array}{r}0.020 \\
(.101)\end{array}$ \\
\hline Age & $\begin{array}{r}-0.112 \\
-(.605)\end{array}$ & $\begin{array}{l}-0.239 \\
-(1.173)\end{array}$ & $\begin{array}{r}-0.034 \\
-(.067)\end{array}$ & $\begin{array}{r}-0.102 \\
-(.202)\end{array}$ & $\begin{array}{r}-0.027 \\
-(.182)\end{array}$ & $\begin{array}{r}0.169 \\
(.931)\end{array}$ \\
\hline Age2 & $\begin{array}{r}0.001 \\
(.423)\end{array}$ & $\begin{array}{r}0.003 \\
(.937)\end{array}$ & $\begin{array}{r}-4.7 \mathrm{E}-05 \\
-(.007)\end{array}$ & $\begin{array}{r}0.001 \\
(.117)\end{array}$ & $\begin{array}{r}2.2 \mathrm{E}-04 \\
\quad .158)\end{array}$ & $\begin{array}{l}-0.002 \\
-(1.086)\end{array}$ \\
\hline High School & $\begin{array}{l}0.242 \\
(1.579)\end{array}$ & $\begin{array}{r}0.153 \\
(.86)\end{array}$ & $\begin{array}{r}-0.026 \\
-(.19)\end{array}$ & $\begin{array}{r}-0.126 \\
-(.823)\end{array}$ & $\begin{array}{r}0.164 \\
(.951)\end{array}$ & $\begin{array}{r}0.095 \\
(.537)\end{array}$ \\
\hline Apprenticeship & $\begin{array}{r}0.037 \\
(.258)\end{array}$ & $\begin{array}{r}-0.126 \\
-(.729)\end{array}$ & $\begin{array}{c}0.167 \\
(1.266)\end{array}$ & $\begin{array}{r}0.074 \\
(.465)\end{array}$ & $\begin{array}{r}0.030 \\
(.274)\end{array}$ & $\begin{array}{r}0.131 \\
(.962)\end{array}$ \\
\hline University Degree & $\begin{array}{r}-0.071 \\
-(.329)\end{array}$ & $\begin{array}{r}-0.181 \\
-(.786)\end{array}$ & $\begin{array}{r}0.047 \\
(.247)\end{array}$ & $\begin{array}{r}-0.065 \\
-(.309)\end{array}$ & $\begin{array}{r}0.122 \\
(.596)\end{array}$ & $\begin{array}{l}0.290 \\
(1.177)\end{array}$ \\
\hline
\end{tabular}

Notes: Numbers under estimated coefficients are z-scores. * , **, *** indicate 10\%, 5\% and 1\% significance, respectively. Other regressors include those listed in Table 2. 
Appendix Table 1. Results Labor Force Participation \& Per Capita HH-Income Regressions

\begin{tabular}{|c|c|c|c|}
\hline & Employment & Participation & Income \\
\hline State Unemployment Rate & $\begin{array}{l}-0.049 * * * \\
-(4.53)\end{array}$ & - & - \\
\hline \# of Children under Age 7 & - & $\begin{array}{l}-0.456 * * * \\
-(11.83)\end{array}$ & - \\
\hline \# of Children under Age 18 & - & $\begin{array}{l}-0.176 * * * \\
-(6.75)\end{array}$ & - \\
\hline Supports specific Party & - & - & $\begin{array}{l}-0.132 * * * \\
-(5.81)\end{array}$ \\
\hline House Owner & - & - & $\begin{array}{r}0.013 \\
(.50)\end{array}$ \\
\hline Living Area per HH-member & - & - & $\begin{array}{l}0.012 * * * \\
(21.57)\end{array}$ \\
\hline Windfall Income & - & - & $\begin{array}{l}0.237 * * * \\
(3.94)\end{array}$ \\
\hline Married & $\begin{array}{l}0.400 * * * \\
(4.79)\end{array}$ & $\begin{array}{l}-0.872 * * * \\
-(12.92)\end{array}$ & $\begin{array}{c}0.115 * * * \\
(2.95)\end{array}$ \\
\hline Male*Married & $\begin{array}{r}-0.015 \\
-(.13)\end{array}$ & $\begin{array}{l}1.356 * * * \\
(10.76)\end{array}$ & $\begin{array}{l}-0.361 * * * \\
-(7.04)\end{array}$ \\
\hline Male & $\begin{array}{r}-0.048 \\
-(.62)\end{array}$ & $\begin{array}{l}0.509 * * * \\
(4.98)\end{array}$ & $\begin{array}{l}0.350 * * * \\
(8.08)\end{array}$ \\
\hline Age & $\begin{array}{l}0.113 * * * \\
\quad(6.7)\end{array}$ & $\begin{array}{l}0.186 * * * \\
(12.04)\end{array}$ & $\begin{array}{r}0.003 \\
(.31)\end{array}$ \\
\hline Age $^{2}$ & $\begin{array}{l}-0.001 * * * \\
-(6.98)\end{array}$ & $\begin{array}{l}-0.002 * * * \\
-(13.39)\end{array}$ & $\begin{array}{r}2.3 \mathrm{E}-05 \\
(.24)\end{array}$ \\
\hline Gov. Health Insurance & $\begin{array}{l}-0.830 * * * \\
-(7.14)\end{array}$ & $\begin{array}{l}0.116 * * \\
(1.99)\end{array}$ & $\begin{array}{c}-0.181 * * * \\
-(5.90)\end{array}$ \\
\hline Body Mass Index & $\begin{array}{r}-0.007 \\
-(1.00)\end{array}$ & $\begin{array}{r}-0.004 \\
-(.88)\end{array}$ & $\begin{array}{r}-0.002 \\
-(.61)\end{array}$ \\
\hline Apprenticeship & $\begin{array}{l}0.310 * * * \\
(4.75)\end{array}$ & $\begin{array}{l}0.215 * * * \\
(3.94)\end{array}$ & $\begin{array}{l}0.102 * * * \\
(3.27)\end{array}$ \\
\hline High School & $\begin{array}{l}0.254 * * * \\
(2.61)\end{array}$ & $\begin{array}{r}-0.045 \\
-(.68)\end{array}$ & $\begin{array}{c}0.205 * * * \\
(5.34)\end{array}$ \\
\hline University Degree & $\begin{array}{r}0.164 \\
(1.30)\end{array}$ & $\begin{array}{l}0.665 * * * \\
(7.35)\end{array}$ & $\begin{array}{c}0.211 * * * \\
(4.47)\end{array}$ \\
\hline Currently Smoking & $\begin{array}{r}-0.116 \\
-(1.15)\end{array}$ & $\begin{array}{c}0.151 * \\
(1.74)\end{array}$ & $\begin{array}{r}0.020 \\
(.43)\end{array}$ \\
\hline Ever Smoked & $\begin{array}{r}0.048 \\
(.62)\end{array}$ & $\begin{array}{r}-0.025 \\
-(.47)\end{array}$ & $\begin{array}{r}0.036 \\
(1.20)\end{array}$ \\
\hline How Many Smoke & $\begin{array}{l}-0.009 * * \\
-(2.49)\end{array}$ & $\begin{array}{l}-0.008 * * \\
-(1.97)\end{array}$ & $\begin{array}{l}-0.005 * * \\
-(2.38)\end{array}$ \\
\hline $\begin{array}{l}\text { \# of Observation } \\
\text { rho }\end{array}$ & \multirow{2}{*}{\multicolumn{2}{|c|}{$\begin{array}{cc}8661 & 1105 \\
-0.493 \\
-(.20) \\
\text { Chi2=6.68, } \operatorname{Pr}(\text { Chi2 }>6.68)<0.0\end{array}$}} & \multirow[t]{2}{*}{8661} \\
\hline LR-Test Indep. Equation & & & \\
\hline
\end{tabular}

